\title{
Trinity, Number and Image. The Christian Origins of the Concept of Person
}

\author{
Graziano Lingua ${ }^{1}$ iD
}

Accepted: 1 March 2021 / Published online: 17 April 2021

(c) The Author(s) 2021

\begin{abstract}
The studies on the history of the notion of "personhood" have largely recognized that Christian thought had a central role in the development and significance of this concept throughout the history of Western civilization. In late antiquity, Christianity used some terms taken from the classic and Hellenistic vocabulary in order to express its own theological content. This operation generated a "crisis" of classical language, namely a semantic transformation in the attempt to address some aspects of reality which were not envisioned by the previous usage of these words. The term person is a paradigmatic example of this process. In fact, from the outset, it played a strategic role in formulating the idea of Incarnation, one of the central doctrines of Christianity. This essay aims to show how, during the first centuries of Christianity, the terms commonly used in order to express the notion of "personhood" (prosopon, hypostasis and persona) became pivotal elements for the formulation of the discourse about the Trinity and progressively acquired new meanings. The analysis focuses only on the initial stage of the elaboration of this concept in Christianity and, based on some of the most significant texts, tries to bring out a series of theoretical problems that may be useful to understand the subsequent debate. In order to do so, the author divides the text in two parts. In the first one, he analyses two features strictly connected to the theological use of the term "persona", which remained central also when this term was later referred to man. These features are individuality and ontological stability, along with the structurally relational status of personhood. In the second part, the author offers more details about the theology of the Cappadocian Fathers, in particular of Basil of Caesarea, and analyses two sectorial languages - mathematical and iconic language - used by Basil in order to describe the intra-trinitarian relationships.
\end{abstract}

Keywords Personhood $\cdot$ Hypostasis $\cdot$ Trinity $\cdot$ Number $\cdot$ Icon

This essay was translated from the italian by Sarah De Sanctis.

Graziano Lingua

graziano.lingua@unito.it

1 Department of Philosophy and Education Sciences, University of Turin, Turin, Italy 


\section{Introduction}

To speak of a person means to speak of a human being. Indeed, one could say that few other terms are so clearly linked to specific qualities that make humanity what it is. With this term we indicate the physical, moral and legal individuality of the subject. We can use it to mean the difference between a human living being and a non-human living being, or to attribute responsibility for something to be answered for morally or before the law. We employ it to speak of human dignity and we inscribe in it a series of inalienable rights. But if we take the Greek and Latin terms that we normally translate as "person", we realize that none of them expresses the same plurality of meanings that we attribute to this word today. The term has in fact undergone a series of semantic shifts that have progressively enriched its meaning, sometimes even radically transforming it. However, it is easy to note that a fundamental step in the history of the term was the transformation that took place in late antiquity thanks to Christianity. Marcel Mauss is right to say: "Our notion of the human person is still fundamentally the Christian notion" [36: 278]; indeed, it is in this religion that the word became charged with a series of elements that would remain essential to the whole history of the concept.

It must be said from the outset that studying the significance of Christianity in the formation of this notion means dealing with a complex semantic transformation that involved most of the concepts of pre-Christian culture during late antiquity. The early Christian writers had to bend the language of the surrounding culture to express a series of doctrinal contents that immediately appeared heterogeneous with respect to the context in which they were formulated. In its universalistic afflatus, of which Paul of Tarsus had become the bearer, Jesus's message had to speak to the Greeks and the Latins in words that they were familiar with, but at the same time it had to convey content that would sound to their ears like simple foolishness (I Cor. 1, 17-31). For this reason, Christianity used terms common to classical and Hellenistic thought (think for example of logos, ousia, prosoppon, hypostasis or, on the Latin side, verbum, substantia, persona), but it did so to express realities that the previous history of these words could not contain [40: 64].

Since the time of the apostles, the Christian faith has felt the need of "always being prepared to make a defense to anyone who asks you for a reason for the hope that is in you" (1 Pt 3, 15). For the first Christian thinkers, providing this reason meant not only announcing the story of Jesus of Nazareth and his message, but also trying to explain and legitimize it rationally, transposing it into the philosophical language that mediated the dominant rationality at the time. This operation was far from inconsequential, so much so that, already at the end of the nineteenth century, the great historian of dogmas Adolf von Harnack argued that the process of "Hellenization" of Christianity and the formulation of a dogmatics had radically altered the essence of Christianity itself [51: 214-221].

In reality, what happened in the early Christian centuries was a much more complex undertaking of transcultural translation and inscription into Hellenistic 
culture of a series of new elements that would eventually transform it from within. Contrary to what according to Horace had happened in Greece, which, being "the captive, made her savage victor [Rome] captive" (Graecia capta ferum victorem cepit) [29: 408], Christianity, which was also victorious in the clash with paganism, bent only in part to the Hellenization of its own thought, triggering instead a conspicuous mirror phenomenon of "Dehellenization" [19: 150; 38: 150-151] of pagan philosophy. What happened was a real crisis of language [40: 64] and of the conceptual framework that supported it. From that moment on, the concepts inherited from Greek thought opened up to new meanings that had a profound return effect on philosophy itself, in an interaction that proved transformative for both interlocutors.

The Christian history of the term "person" can be considered a paradigmatic case of this crisis that affected classical language once it became involved in the work of religious inculturation. Think only of the context within which the various words indicating the notion of person were used: this is enough to note an evident break with the past. Contrary to what one would naturally expect, the conceptual work on these terms did not take place in early Christianity in reference to the human being, but rather in reference to God and specifically to the meaning to be attributed to the nature of Christ. The terms borrowed from the dominant culture-prosopon, hypostasis and persona-became theological operators with which to formulate one of the fundamental theological questions: how to reconcile monotheism with Jesus of Nazareth's claim to be God himself and not just a simple prophet?

What was at stake was nothing less than the doctrine of the Incarnation and the challenge to express both the meaning of Jesus's claim and the new internal configuration of the divine being it involved. If it is God Himself who incarnates Himself in a determined historical individual, then the divine being is not monolithic, but in itself differentiated, and it is therefore necessary to think of this difference without breaking its unity. As is well known, the outcome of these discussions will be the Trinitarian formula still used today by Christianity, according to which God is "a substance in three persons", but its elaboration was laborious and required centuries of clashes and debates.

Why was the notion of person so involved in this discussion as to become one of the main issues at stake? What return effects did this passage through theology have on the semantic stratification of the terms involved and on the subsequent conceptualization of the person? Instead of roughly reconstructing the doctrinal and linguistic events involved in the Christological and Trinitarian debates of the early Christian centuries - an operation that has been conducted on several occasions in recent dec$\operatorname{ades}^{1}$ - I will try to answer these questions in a different way. In this essay I will address the issue of the Christian "invention" of the person by proposing a two-step path. First of all I will dwell briefly on some transformations that the ancient lexicon underwent when the specific language of Christianity was created, trying to show how, precisely because of the need to speak of God and not of humanity, two orders of problems emerged: on the one hand the question of the person as an ontologically

\footnotetext{
${ }^{1}$ See $[27 ; 31 ; 37 ; 38]$.
} 
stable individuality, on the other its intrinsically relational dimension. These issues on the theological side then led to the anthropological transposition that would take place over the centuries.

In the second part I will isolate a specific stage in the Trinitarian debate: the theology of the Cappadocian Fathers and their use of the term hypostasis to express the ontological characteristics of individual Trinitarian persons. The essentialist approach of the Cappadocians has led many interpreters to criticize their tendency to overemphasize the diversity of the persons to the detriment of their relationship and the unity of the divine being. Against this interpretation I will try to show how, even in this fundamental phase of the first Trinitarian elaboration, there was a personological-relational instance at work from within the essentialism of the Greek metaphysical language.

In order to shed further light on this, I will conclude with a brief analysis of some texts by Basil of Caesarea, following two sectorial languages that he uses to describe the intratrinitarian relationship: the mathematical language and the iconic language. The number and the image will help show that Basil, while elaborating his own personological semantics with strictly ontological categories, preserved the instance of relationship and communion as a fundamental characteristic of the person in the Trinitarian realm. The properly linguistic aspect of this exercise would always be at the service of the doctrinal element to be transmitted, which consists in the challenge of conceiving the paradoxical compossibility of two irreconcilable extremes: the radical unity of the divine being and its concrete difference, which in order to maintain unity cannot but manifest itself as a difference in the relationship.

The objective of this essay is therefore very limited, both from a historical point of view and with respect to the corpus of texts under analysis. The first Christian centuries make up only one of the germinative stages of the notion of person, and in order to grasp its development up to contemporary use it would be necessary to address the continuities and breaks that this concept has experienced in the last two millennia, not only on the philosophical-theological side, but also, at least, in the history of law. Nevertheless, in the pages that follow, I intend to show that it was precisely in this period that certain basic conceptual structures took hold, without which the subsequent history of the term would be incomprehensible.

\section{Prosōpon, Hypostasis and Persona}

Let's start with some terminology. As said before, the concept of person is expressed in Greek with the two terms prosopon and hypostasis-both used at different times in Trinitarian disputes to express the ad intra distinctions of God's life-and with the Latin term persona, which was used in the Trinitarian context by Tertullian in the Adversus Praxean [48]. In order to grasp the semantic transformation that would take place in Christianity, however, it is necessary to recall what the meaning of these terms was in classical Greek and Latin culture.

The Greek word prosopon, despite being often associated directly with "mask", actually had a much broader meaning in common language [26: 81]. This can be inferred from its etymology, composed of the proposition pros (in front) and the 
radical ops (from orān, to see) [20: 40]: that is, what is in front of the eyes and therefore the visible part of an object, or, if referred to a human being, their face. For this very reason, prosopon indicated the way in which an individual appeared externally. The term therefore contained an essential relational element, so much so that it progressively acquired the sense of "social role" [32: 39]. Only in the Hellenistic period "did it indicate the pars pro toto and therefore the individual man in his position within society" [38: 54].

The specific use of the term prosopon in classical Greek to indicate a mask or, more generally, a character in a theatrical performance [43: 279-284] could have suggested the notion of something apparent and fictional. This appearance-related aspect, then, could have made it difficult at first to use prosopon in Trinitarian theology [45: 161; 14: 11], because it led one to think that the three Trinitarian persons were only modes of appearance of the one God, as Sabellianists would posit, for example. However, as George Prestige remarks, "no ancient Father until Basil uses the word prosopon in this sense of mask. When the word is employed to describe the Persons of the Trinity, it means, not a transitory and superficial presentation, but simply an individual.'[45:113]. Similarly, already in the Greek Septuagint translation, which would have great importance in Christian conceptual elaboration, the word prosoppon (which recurs more than 850 times) did not have this fictional trait and indeed, in most cases, it served to convey the Hebrew panim, face, and was also used in reference to the face of Yhwh [38: 54].

Hypostasis is instead a technical term, mostly used in scientific and medical language to indicate the simple objective existence of an entity, as distinguished from appearance or subjective impression [38: 92; 17: 43-44]. In stoic philosophy, hypostasis indicates the way in which the substance [ousia] materializes into an objective individual reality [26: 83; 38: 92-93]. Neoplatonism would accentuate this link between ousia and hypostasis by considering each hypostasis a manifestation of the One, from which it emanates [38: 93]. The term therefore tended to indicate the concrete singularity and reality of things insofar as the ousia individualizes and takes shape in them, so much so that it can be linked to the Latin notion of subsistentia [26: 83]. Precisely this individualizing dimension made the term a fundamental instrument to express the intratrinitarian difference of the Father, the Son and the Holy Spirit.

Instead, the origin of the Latin word persona is more complex to define and the etymological debate about it is still open. The etymology proposed in the first century B.C. by Gavius Bassus in the lost work De origine vocabulorum (testified in Aulus Gellius' Noctes Atticae [38: 64]) posited that persona derived from the verb personare, "to make (sth) resonate", by analogy with the meaning of "theatrical mask" that the term had in classical Latin. More likely, however, persona derives from the Etruscan term phersu [38: 64]. Alongside the main meaning of "mask", in stoic philosophy the term acquired, through a metonymic translation, the more general sense of "social role" and, more globally, of "individual", understood as the subject of rights and duties. Cicero uses this meaning in his work De officiis, noting how officials represent the state (se gerere personam civitatis [13: 126-127]). This sense was also used in Roman law, so much so that in the second century A.D. Gaius arranged the macrostructure of his Insitutiones by distinguishing between laws for 
people (personae), for things (res) and for actions (actiones) [21: 3]. The term persona means in this case "legal actor" and is used for both free men and slaves. The ideas of social role, function and juridical identity contributed to give the term a precise social value, keeping together the element of individuality and that of relationality, which the Greek pair hypostasis and prosopon tended to separate.

This brief analysis alone is enough to show why these terms would become so central to theological controversies. "Person" is the strategic notion based on which Christian thinkers of the early centuries, in a complex process of theoretical elaboration, tried to express the difference within God without this breaking the unity of the divine. With this concept they therefore negotiated two demands posed by the confession of Jesus's divinity: on the one hand, the real distinction between different ontologically consistent singularities in God and, on the other, their intrinsic unitary relationship.

In the first two centuries this uni-trinitarian conception of God was expressed more on a practical-experiential than on a theoretical level. This can be clearly seen in the liturgical formulas of Baptism and the Eucharist, as attested, for example, by the writings of Justin Martyr [30: 238-239, 254-255]. Very soon, however, Christianity felt the need to deepen the theological understanding of its meaning, both for internal needs dictated by the necessity of staying faithful, over time, to the experience of its origins, and for external needs, in order to explain and defend the doctrine that was being elaborated [15: 162].

\section{The Concept of Person in Trinitarian Debates}

When Latin Christians had to express the intratrinitarian distinction they had no difficulty in using the term persona, because the word expresses in itself both the dimension of real and objective identity and the relational dimension. Tertullian spoke explicitly of three persons and adopted the term trinitas for the first time [48: 1161-1162]..$^{2}$

For the course of his arguments it is of decisive importance that in the Sacred Scripture he sees different voces dialoguing with each other. [...] But these are not only roles, 'dramaturgical personalities', but - and here comes into play the meaning marked by the prior history of the concept and by its everyday linguistic use - truly distinct individuals [26: 88].

It must be said, however, that even if the common meaning of persona presented itself as an adequate instrument to express the unity-trinity of God, Latin Christianity took some time to fully adopt Tertullian's position, because what prevailed was the interest in emphasizing the unity of the divine substance, rather than the plurality of persons. In the early Christian centuries, in fact, as the history of dogmas [47: 131; 26: 64-71] has amply pointed out, the theological discourse roughly followed

${ }^{2}$ On the trinitarian theology of Tertullian see [28; 39; 42: 194-209]. 
two great conceptual matrices: on the one hand the Latin theologians, who started from the unity of the divine substance and arrived only secondarily at the trinity of persons, conceiving them starting from their relations of origin; on the other hand, the Greek theologians, who emphasized the trinity of the persons and formulated their unity through the relationships between them. The unity of God in the latter case was not understood as an essential, formal and pre-hypostatic unity, because it was already realized in a personal form, in the "monarchy" of the Father [26: 69].

It is thus understandable why the semantic elaboration of the notion of person would develop the most in the Greek tradition. As we have seen, in fact, in the Greek used by the first Christians the term prosoppon was not so easily applicable to express the intratrinitarian difference, because it contained a semantic value that was inclined towards the idea of role and character. In particular, it failed to express the dimension of ontological individuality that was necessary to ensure that trinitarian persons did not appear only as simple names or fictional modes. That is why in the early centuries AD prosōpon was rarely used to express the difference between Father, Son and Holy Spirit. Rather, the choice fell on the technical term hypostasis, which best expressed the stability of single individuals and their ontological distinction [28: 394].

However, even the latter term was full of ambiguity because it was used in Neoplatonic emanationism to describe the different lower degrees that descend from the One to the many. Origen, the Greek writer of the third century who first used it in the Trinitarian discourse [38: 97], is an example of the subordinationism risks that were linked to the Neoplatonic meaning of hypostasis. For him, in fact, the hypostasis of the Son was inferior [deuteros] to that of the Father, the only God in the strict sense [31: 128], inasmuch as He is ungenerated [agenetos] [44:54]. His doctrine would be the breeding ground for the development of Arianism, a theological position that affirms the rigorous unity of God and considers every form of mediation of the principle, including the Son, as inferior and derived. Arius' subordinationist Christology had no difficulty in using the term hypostasis to indicate the person of the Son, but interpreted this term loading it with the same ontological meaning as ousia, so that the Son had a distinct individuality of his own, related to the Father only by derivation [38: 105]. Since God had to be one, only the hypostasis of the Father could be fully divine, while any other hypostasis had to be considered ontologically inferior.

Against subordinationism, the First Council of Nicaea (325) introduced the idea of consubstantiality between the Father and the Son. The adjective homoousios [of one substance] used by the Council is very interesting because it is a product of dogmatic elaboration that was not found in the Scriptures. This term was used to indicate the identical degree of being between Son and Father, giving theological value to the concept of ousia, a notion that served to express God's original unity. In reality the First Council of Nicaea did not resolve at all the controversy, because the consensus reached was interpreted differently by the various parties involved [31: 237-251]. What was particularly problematic at this point was the meaning to be attributed to the unity of substance between the Father and the Son (also because the third person, the Spirit, would only enter the debate later). Once the Son's equidivinity had been determined, in fact, his unity with the Father had not yet been 
established. Athanasius would be the one to explicitly define the unity and identity between Father and Son and he would also apply the idea of consubstantiality not only to the Son, but also to the Spirit. ${ }^{3}$

At this point in the development of the Trinitarian debate, however, a further difficulty arose. The formula "one ousia in three hypostaseis", a substance in three persons, which began to become dominant after Athanasius, emphasized the separate subsistence of the Father, the Son and the Spirit, rather than the one and indivisible nature common to the Three [31: 264]. Today we are used to thinking that the two concepts of substance and hypostasis have a distinct meaning, where one serves to express the unity of God and the other to convey His threefold personality. In fact, however, in the fourth century the two terms both indicated basically the same thing [28: 394-395], i.e. substance, and hypostasis did not immediately mean person, as we have seen, but a real entity manifested in a concrete singularity-so much so that it was also used for inanimate objects [38: 92-93]. Identifying substance and hypostasis in God therefore ran the risk of shattering monotheism by transforming it into a tri-theism, in which the hypostases, having an autonomous ontological identity, were separated.

\section{The Cappadocian Theology: Ousia and Hypostasis ${ }^{4}$}

The Cappadocian Fathers (Basil of Caesarea, Gregory of Nyssa and Gregory of Nazianzus $)^{5}$ tried to find a solution to this problem by working to untangle the conceptual ambiguities contained in the notion of hypostasis. As Pavel A. Florenskij pointed out, their most innovative contribution, in the wake of Athanasius, was precisely to take two terms, hypostasis and ousia, which basically meant the same thing, to express the common origin of two aspects of the immanent Trinity: unity and trinity, which risked being conceived as separate [18: 41-43]. This theoretical move thus countered two different tendencies present in the fourth century, and which would constantly recur in the developments of Trinitarian theology: modalistic monarchianism, which ended up thinking of persons as mere manifestations in God's actions in history, and tritheism which instead split God's unity into three deities that were similar, but not identical in substance (hence the use by some authors of the term homoiousios, instead of homoousios [31: 238; 18:41]).

The effort to keep together the dimension of unity with that of difference was achieved by these Fathers through the epistemological and ontological distinction and interrelation between theologia and oikonomia, that is, between a discourse that attempts to express the immanence of God (theologia), and a discourse that starts

\footnotetext{
3 On Athanasius' trinitarian theology see [12: 23-27; 38: 110-116].

${ }^{4}$ For a more in-depth analysis of these aspects I refer the reader to my paper G. Lingua, L'Uno e le sue differenze. Figure e temi del pensiero trinitario nel cristianesimo orientale (forthcoming), of which I am quoting some parts in this essay.

5 For a general introduction to the study of the thought of the Cappadocians one can consult $[2 ; 33 ; 41]$. On Basil's theology see in particular [46].
} 
instead from the peculiarity of the historical-concrete manifestation in which the hypostases are revealed. Thanks to this distinction, it is evident that the immanence of God cannot be spoken of without starting from His action in the world, that is, from oikonomia.

It is precisely oikonomia that allows us to understand the peculiarity of individuals, what Basil calls their individual characters [ta idiomata], because it is their economy of manifestation that shows us the difference inherent in the divine being. The Father manifests Himself in the generation of the Son and in the creation of the world, the Son in his mission on Earth, and the Spirit in his capacity for sanctification. From this point of view, according to Basil, the relationship between the unity of substance and the diversity of the hypostases should be read in analogy to the relationship between what is common and what is particular:

If we are to say briefly what we think, we shall speak as follows: what the generic idea is to the particular, this the substance is to the person. For not only does each one of us participate in "being" in the common meaning of "existence," but So-and-so "exists" in respect to his own individual traits, and so does So-and-so. So even here the concept of existence or substance is generic, like goodness, divinity, or any other abstract concept; but the person is perceived in the special character of fatherhood, or sonship, or of holy power. [4: 234-235]

In God, the hypostasis is concretized in the individual properties, which are fatherhood, sonship and the sanctifying power. With this distinction Basil does no more than identify ousia with the Aristotelian second substance and hypostasis with the first substance [1: 18-19; 38: 93]. In Epistula XXXVIII, ${ }^{6}$ attributed to Basil but perhaps written by Gregory of Nyssa, the rainbow metaphor is used to express the fact that, despite the multiplicity of manifestations, there is no division and each person has a distinctive character [3: 212-217]. Only the Father is not originated, because $\mathrm{He}$ is pure potentiality, a potentiality that, however, must express itself and become in actuality, in the Son through generation and in the Spirit through procession. The Son "shines forth as the only-begotten from the unbegotten light" [3: 206-207]. Through him, as in a mirror image, it is possible to know the Father and with him also the Holy Spirit, "for it is impossible for a man, if he has not been previously enlightened by the Spirit, to arrive at a conception of the Son" [3: 206-207]. Finally, the Spirit comes from the Father and is distinguished by the fact "that He is produced after the Son and with Him and that He has His subsistence from the Father" [3: 206-207].

Basil's approach was further developed by his younger brother Gregory of Nyssa and by Gregory of Nazianzus. In fact, an interesting document to grasp the transformations of the semantics of the person is Oratio XLII, written by the latter [24: 48-115; trans. 25: 385-395]. Here, dealing with the Trinitarian terminology, Gregory of Nazianzus maintains that to speak of hypostasis in God does not mean to

\footnotetext{
${ }^{6}$ On the debate concerning Basil's authorship of this letter see [5: 407-408; 3: $\left.197 \mathrm{ftn} 1\right]$.
} 
divide the one nature into three different substances and that to use, as some do, the term prosoppon does not mean to imagine the One as "a single compound sort of being, with three faces" [24: 84; trans. 25: 391]. ${ }^{7}$ Gregory of Nyssa, whose speculative afflatus surpasses the other Cappadocians, wrote the treatise Ad Ablabium [22: 37-57] precisely to answer the question of how to reconcile the unity of substance and the trinity of hypostases without falling into contradiction. ${ }^{8}$ In it, Gregory countered the accusation of tritheism that had been put forward against the theology of the Cappadocians by claiming that the three hypostaseis are ways of the divine essence that do not divide it, so theos, the term that indicates this essence, must always be used in the singular [38: 129].

The effort of the Cappadocians to distinguish between the unity of ousia and the difference between persons may appear somewhat formal, but it must not be forgotten that the scenario within which they conducted their doctrinal battles was never pure philosophical speculation. The objective was in fact soteriological: it was necessary to give meaning to the claim of salvation contained in the message of Jesus Christ, justifying his divinity, and to do this it was necessary to stretch from within the conceptuality inherited from Greek philosophy. The work done on the meaning of hypostasis thus ended up radically changing Greek metaphysics, because it shifted attention from the universality of being to the singularity of substances.

Previously, as Andrea Milano points out well, "the Greeks placed the truth in the universal. In the individual they always sought that which transcends it. Man in his concrete singularity had no value worthy of note" [38: 132]. The Cappadocians, bringing hypostasis to the forefront as an entity that exists individually in itself, inaugurated, on the theological side, the valorization of the individual which would then have important anthropological repercussions. On the other hand, the Christian message - centred on the faith of the individual and on the need for individual salvation-could not be satisfied with a metaphysical system that placed an impersonal cosmological order at its center.

Interpreters are deeply divided on the meaning to be attributed to this primacy of hypostatic identity in the Cappadocians. The fact that it was formulated within a substantialistic ontology such as the Greek one and that the terminological work took place at the theological level would seem to represent an insurmountable hiatus with respect to what the person would become at least after the sixth century, with the famous definition given by Boethius "naturae rationalis individua substantia": an individual substance of a rational nature [11: 84-85, 92-93]. While recognizing this essentialism, one cannot underestimate the importance of the Cappadocians' effort to hold together the individual identity of divine persons with their communional relationship [koinōnia]. ${ }^{9}$ Having to express the relationship of unity between hypostases they were led to think of individuality as intrinsically correlated and thus "the distinction between ousia and hypostasis, which initially rested

\footnotetext{
${ }^{7}$ On the trinitarian theology of Gregory of Nazianzus, see [9: 187-233; 42: 564-569].

${ }^{8}$ On the same question, see [23].

${ }^{9}$ On the "koinonial" relationality between the three hypostases in the Cappadocian trinitarian logic, see [2].
} 
on the 'essential-natural' level, began to specify itself in the direction of a personal thought" [26: 91].

\section{Basil: The Language of Number and Image}

In conclusion, in order to show how this relational dimension is articulated, it is interesting to analyze the use that Basil of Caesarea makes of two metaphorical languages of the relationship: the mathematical language and the iconological one.

Regarding the first language, the trinitarian formula eis ousia, treis hypostaseis immediately refers to the question of number and the paradoxical relationship of identity that the 1 comes to have with the 3 . However, can we legitimately speak of God using the category of quantity that is typical of intra-worldly entities? What can it mean then, from a mathematical point of view, that 1 and 3 are identical and that the three persons are one substance, despite identifying each as itself? Basil answers these questions by analyzing the type of operation that is involved in the uni-trinity. He talks about it in one of the most famous paragraphs of De Spiritu Sancto:

For we do not count by way of addition, gradually making increase from unity to multitude, and saying one, two, and three, - nor yet first, second, and third. For "I", God, "am the first, and I am the last". And hitherto we have never, even at the present time, heard of a second God. Worshipping as we do God of God, we both confess the distinction of the Persons, and at the same time abide by the Monarchy. [7: 404; trans. 6: 28]

Even if each of the hypostaseis is one, they cannot be added together because the divine nature in which they participate is simple and indivisible. Likewise, they cannot be counted because only finite things can be counted, and infinite things cannot. Now, when it is said that God is one and triune, one necessarily uses the language of number, but Basil insists that one must do so in a reverent way [eusebōs] [7: 404; trans. 6: 28]. The dangers inherent in mathematical terminology can be seen well in the use that the Pneumatomachi ${ }^{10}$ make of the concept of sub-numbering [uparithmēsis] referring in particular to the Spirit, who should be counted as inferior to the Father and the Son, giving rise to an evident subordinationism [7: 414; trans. 6: 30].

In order to avoid this drift, to express the co-presence of 1 and 3 Basil proposes the verb synarithmein (to co-number) [7: 397-400; trans. 6: 26-27], or even more radically enarithmein, (to in-number) [8: 152-153], thus seemingly alluding to an intensive operation, which instead of being linear considers the relationship between 1 and 3 as a centripetal condensation dynamic. To sub-number would mean to fractionate the one substance and therefore once again to claim that the divine being is subject to the regime of quantity - that is to say, that God extends linearly onto

\footnotetext{
10 The Pneumatomachi or Macedonians were a group that denied the full divinity of the Holy Spirit. They followed the bishop of Constantinople Macedonius, who was later deposed by the Arians in 360.
} 
several successive elements. Basil wonders: "Is it not the fact that things when numbered remain what they naturally and originally were, while number is adopted among us as a sign indicative of the plurality of subjects?" [7: 400; trans. 6: 27]. When speaking of the uni-trinity, number should therefore be understood neither in quantitative terms (as a natural number identifying a finite set), nor according to a temporal or spatial succession (as before and after, what is in front and what is behind).

In this second case, in fact, there would be a unity of substance resulting from composition, as if the divine being were the sum of the being of the three persons who manifest themselves and come into action at different times. Rejecting this succession - as Gregory of Nyssa would also do [35: 103-104] — Basil distanced himself from the ontological conception of number that was typical of Neoplatonism, according to which the original Triad was hierarchically composed, and instead referred numbers to the objective reality of Creation. The nature of numbers itself is therefore extraneous to the reality of the divine uni-trinity, because divine reality transcends the operations of mathematics that are only suitable for created things.

We confess one God, not in number but in nature. For not everything that is called one in number is one in reality nor simple in its nature; but God is universally admitted to be simple and uncompounded. Yet God is not therefore one in number. [3: 52-53]

So when we use numbers to express the unitrinarity of the divine being we are actually transfiguring it and projecting it from finitude to infinity. This is why it is particularly interesting to note the use of the verb "to in-number" [enarithmein], which seems to express an intensive form in which the 3 is immediately related to the 1 and the 1 is not given except in the concrete form of the 3 . In the following theology this intensive reality of the Trinitarian relation would be expressed by the notion of perichōressis (circumcessio in Latin) passing from the mathematical metaphor to the geometric one of the "rotation from a fixed point back to that point again" [45: 294]. Also in this case the geometric language would be used to express recursiveness rather than succession, alluding to the figure of the circle where each point can be both start and end at the same time. The image of perichōrēsis, which in Greek recalls dance, would express the mutual in-existence of the Trinitarian hypostases that are fully themselves only thanks to their relationship of mutual exchange.

This same dimension of reciprocity was expressed by Basil through a particular use of the iconic vocabulary. While mathematical language could be used negatively, to mitigate errors in the interpretation of the uni-trinity, the iconic vocabulary and the notion of image, according to Anca Vasiliu [49: 194-217], came to determine the very basis of the Trinitarian debate [49: 193]. In order to understand this aspect, it is worth reporting in full another passage from De Spiritu Sancto that would be taken up on several occasions in the debate on the images of the following centuries.

One Form, so to say, united in the invariableness of the Godhead, is beheld as if in a mirror [eneikonizomenen] in God the Father, and in God the Only begotten. For the Son is in the Father and the Father in the Son; since such as 
is the latter, such is the former, and such as is the former, such is the latter; and herein is the Unity. So that according to the distinction [idioteta] of Persons, both are one and one, and according to the community of Nature, one. How, then, if one and one, are there not two Gods? Because we speak of a king, and of the king's image [eikōn], and not of two kings. The majesty is not cloven in two, nor the glory divided. The sovereignty and authority over us is one, and so the doxology ascribed by us is not plural but one; because the honour paid to the image passes [diabainei] on to the prototype. Now what in the one case the image is by reason of imitation, that in the other case the Son is by nature; and as in works of art the likeness is dependent on the form, so in the case of the divine and uncompounded nature the union consists in the communion [koinonia] of the Godhead. [7: 406; trans. 6: 28, modified]

First of all, it should be noted that Basil gives a different meaning to the term eikōn compared to the late antique one, where the notion evoked an ontological degradation with respect to a model [49: 193]. Here, instead, the iconic relationship is not analogical-degradative, but homological, i.e. it addresses the identity of meaning. The image of the king is nothing other than the king himself, it does not double it, nor does it split his royal power. Although qua image it constitutes a specific morphological identity (a portrait is not the prototype [50:14]), it expresses a principle of common reality. This is because the image has a transitive power, it makes glorification pass from the eikōn to the prototype, so it puts two morphologically different entities in direct relation. ${ }^{11}$

In this text, the strength of the homological relationship of the image comes into play in two dimensions, one linked to the hypostasis of the Son, the other to the intra-trinitarian relationship. In the first case the concept of image expresses the link between hypostasis as the identification of the substance and prōsopon as the external manifestation of this individuality through the specific form that each person takes from the economic point of view [50: 15]. The use of the term eikonn therefore makes it possible to bind the form with which the Son is seen with knowledge about his essence, that is, with his immanent identity that resides in intratrinitarian communion [koinonia]. Later in the work Basil affirms: "to say that the Son is with the Father is to exhibit at once the distinction of the hypostases, and the inseparability of the fellowship [tēs koinonias]" [7: 460; 6: 37].

The second function of the iconological vocabulary is even more interesting. Vasiliu links it to Basil's use of the verb eneikonizein, "to reflect oneself as in a mirror"- - or, according to the translation proposed by Vasiliu, "to manifest one's own visible form in" [49: 202]— to express the horizontal unity between the individual hypostases, or rather to convey the form of their relationship. Here the relationship is expressed through the idea of reflective interaction, which translates into mutual

\footnotetext{
11 This transitive dimension of the image and the fact that the honor addressed to it passes to the prototype would be taken up several times by subsequent iconophiles. For further details, I refer the reader to [34: 70ff], and for the Christological aspects of the theology of the Byzantine icon, to [10: 237-256].
} 
recognition in honor and into a referral of this recognition to the single substantive model. It follows that the form in which the divine substance is given is the image, as the ability to express at the same time the unity of God and His difference, not only on the vertical side of the relationship between God and man (the Christological side), but also on the horizontal intra-trinitarian side of the persons.

Using the image as an intratrinitarian relationship operator, Basil takes an important step also from the point of view of the personological lexicon, because the reflective power of eikon manages to hold together the ontological subsistence dimension of hypostasis and the role played by prosopon as manifestation. The prosopa of the Father, the Son and the Spirit become the manifestation of their hypostaseis at the very moment when they force hypostatic subsistence from within towards the relationship of reciprocal reflexivity. "It is not sufficient to enumerate the difference in the Persons, but it is necessary to confess that each Person subsists in a true personality" [4: 210-211], because only in this way can Sabellian modalism be avoided.

Basil thus anticipated the progressive condensation that would later occur between the instance of ontological identification contained in the term hypostasis and the instance of relational manifestation that is instead enclosed in the term prosoppon. He therefore made these words coessential to express the person at the theological level, preparing the ground for the transfer of this discourse to the anthropological level that would take place in the following centuries.

\section{Conclusion}

The analysis of the language of number and image in Basil shows how the semantic transformations undergone by the term person are also rich in consequences from a conceptual point of view. The choice of the Cappadocians to correlate the meaning of hypostasis not only to individuality, but also to the relationship, shifted the semantic horizon of this word: from referring only to the dimension of substance, it opened up to what would later become the concept of person and its use in reference no longer to God, but to the human being. Basil's claim that every prosopon exists in a true hypostasis shows the fusion of two aspects which were originally separate and which had made it difficult to use prosopon in the Trinitarian discourse. The unrepeatable singularity indicated by the concept of hypostasis is thus combined with the meaning of social role that was contained in the original sense of the terms prosōpon/persona as an intersubjective manifestation, balancing the fictional dimension that was present in the latter. After the Cappadocians it then became natural in the Greek context to consider prosōpon and hypostasis as equivalent [28: 395], so much so that the Second Council of Constantinople (553) would take this parataxis for granted [38: 141].

On the other hand, the semantic refinement of the term hypostasis that took place in Trinitarian debates resulted in an equally important kinship between the individual's being-for-himself and his belonging to a common nature, a meaning that hypostasis inherited from its original equivalence with ousia. When the question was transposed from theology to anthropology, and Boethius' definition naturae 
rationabilis individua substantia was affirmed in the Latin Middle Ages, the specificity of the individual human being as a person thus maintained an insurmountable correlation with a common humanity. Without this aspect it would not have been possible in modernity to recognize human dignity as a universal characteristic and to attribute equal rights to all persons as such. The analysis of these developments goes beyond the scope of this essay and would require a completely different investigation. It is worth mentioning, however, that the notion of person, conceived solely based on the fictional matrix (which was predominant in the Greek term prosopon and in the Latin term persona) could not have acquired such an ontological weight as to justify linking dignity to its nature, and not only to the action and role that the individual embodies in the social space.

Certainly the gain in ontological terms, which Christianity obtained by using the personological lexicon in the context of the discourse on God, has also led to a tendency to substantiate the notion of person at the expense of a real inter-personal dimension. For example, the use made of the term koinonia by the Cappadocians and Basil in particular, in the Trinitarian context, remains controversial: according to some authors it should be read in continuity with Greek metaphysics - it therefore belongs to the "language of essence" [16: 144] and has no interpersonal or dialogical value. In reality, as I have tried to show by analyzing the use of the metaphors of number and image, Basil can be considered a typical case of the "crisis of language" that occurred in the early Christian centuries: in fact, he stretched from within the semantic closures of the classical terms in use based on the theological content that had to be expressed, thus paving the way for new meanings.

By progressively unifying the meaning of hypostasis and prosōpon to express the internal dynamics of God's life, the Christian Theologians created the conditions for the notion of person to hold together both the profile of individuality and openness to otherness. The latter, from the theological point of view, could not only be the consequence of a static unity of divine substance, but had to be thought of as a personal relationship between the Father, the Son and the Holy Spirit, because only in this way could one make sense of the Christological event and of Jesus' claim to call God "Abba", Father. Moreover, it is no coincidence that Tertullian had founded his Trinitarian conception on the presence in the Scriptures of different voces, that is, of different persons in dialogue with one another in God [38: 71-72]. Such an accentuated "personal" dimension was not only unthinkable in Greek substantive metaphysics, but was not even present in the original meaning of hypostasis, prosopon and persona. By introducing it for theological reasons, early Christian thought has thus prepared the ground for an understanding of the human person which could only be fully expressed in modernity and which would form the basis of the semantic richness that characterizes this term today.

Even if many centuries separate us from the work done by these Christian writers, and even if today we are accustomed to linking the term person to human reality and not to theological questions, it may therefore be important to reappropriate this past, in the awareness that it has left significant traces in our language. Working on these traces does not only respond to a legitimate historical interest, but can serve to better orient ourselves critically in the uses and misuses of the term person today. 
Funding Open access funding provided by Università degli Studi di Torino within the CRUI-CARE Agreement.

\section{Declarations}

Conflict of interest The authors declare that they have no conflict of interest.

Open Access This article is licensed under a Creative Commons Attribution 4.0 International License, which permits use, sharing, adaptation, distribution and reproduction in any medium or format, as long as you give appropriate credit to the original author(s) and the source, provide a link to the Creative Commons licence, and indicate if changes were made. The images or other third party material in this article are included in the article's Creative Commons licence, unless indicated otherwise in a credit line to the material. If material is not included in the article's Creative Commons licence and your intended use is not permitted by statutory regulation or exceeds the permitted use, you will need to obtain permission directly from the copyright holder. To view a copy of this licence, visit http://creativecommons.org/licen ses/by/4.0/.

\section{References}

1. Aristotle. 1962. The categories. On interpretation. Prior analytics, trans. by H.P. Cook and H. Tredennick. Cambridge, MA: Harvard University Press.

2. Awad, Najeeb G. 2007. Between subordination and koinonia: Toward a new reading of the Cappadocian theology. Modern Theology 23: 181-204.

3. Basil. 1926. Letters 1-58, trans. by R. J. Deferrari. Cambridge, MA: Harvard University Press.

4. Basil. 1986. Letters 186-248, trans. by R. J. Deferrari. Cambridge, MA: Harvard University Press.

5. Basilio di Cesarea. 1983. Le lettere I, ed. M.F. Patrucco. Torino: SEI.

6. Basil. 1995. Letters and Selected Works. In A Select Library of the Christian Church Nicene and post-Nicene Fathers, Series II, Vol. 8, ed. Ph. Schaff and H. Wace. Peabody, MA: Hendrickson Publishers, Inc.

7. Basile de Cesarée. 1968. Sur le Saint-Esprit, ed. Pruche (SCh 17bis). Paris: Cerf.

8. Basile de Césarée. 1982-1983. Contre Eunome, ed. B. Sesboüé, G.M. de Durand and L. Doutreleau (SCh 299; 305). Paris: Cerf.

9. Beeley, Christopher. 2008. Gregory of Nazianzus on the Trinity and the knowledge of God: In your light we shall see light. Oxford: Oxford University Press.

10. Bernardi, Piergiuseppe. 2013. Il Logos teandrico. La "cristologia asimmetrica" nella teologia bizantino-ortodossa. Roma: Città Nuova Editrice.

11. Boethius. 1968. The theological tractates, trans. by H.F. Stewart and E.K. Rand. Cambridge, MA: Harvard University Press.

12. Bulgakov, Sergius. 2004. The Comforter, trans. by B. Jakim. Grand Rapids, MI: Eerdmans.

13. Cicero. 1928. De officiis, trans. by W. Miller. London: William Heinemann Ltd - New York: G.R. Putnam's Sons.

14. Clark, Mary. 1992. An inquiry into personhood. The Review of Metaphysics 46: 3-28.

15. Coda, Piero. 1993. Dio Uno e Trino. Cinisello Balsamo: San Paolo.

16. De Halleux, André. 1986. Personnalisme ou essentialisme trinitaire chez les Pères cappadociens ? Une mauvaise controverse (première partie). Revue théologique de Louvain 17: 129-155.

17. Dörrie, Heinrich. 1955. Hypostasis. Wort- und Bedeutungsgeschichte. Nachrichten der Akademie der Wissenschaften in Göttingen 1: 35-92.

18. Florensky, Pavel A. 2004. The pillar and ground of the truth: An essay in orthodox theodicy in twelve letters. Princeton, NJ: Princeton University Press.

19. Forte, Bruno. 1988. Gesù di Nazareth. Saggio sul Dio cristiano. Cinisello Balsamo: Edizioni Paoline.

20. Frontisi-Ducroux, Françoise. 1995. Du masque au visage: aspects de l'identité en Grèce ancienne. Paris: Flammarion.

21. Gaius. 1939. Institutiones, ed. E. Seckel and B. Kübler. Leipzig: B.G. Teubner. 
22. Gregory of Nyssa. 1958. Quod non sint tres. Ad Ablabium, ed. F. Mueller. [GNO. Vol. III/1: 37-57]. Leiden: Brill.

23. Grégoire de Nysse. 2008-2013. Contre Eunome I-II, ed. R. Winling (Sch 521; 551). Paris: Cerf.

24. Grégoire de Nazianze. 1992. Discours 42-43, ed. J. Bernardi (Sch 384). Paris: Cerf.

25. Gregory of Nazianzus. 1995. Select Orations, trans. by Ch.G. Browne and J.E. Swallow, in A Select Library of the Christian Church: Nicene and Post-Nicene Fathers, Series II. Vol. 7, ed. Ph. Schaff and H. Wace. 203-853. Peabody, MA: Hendrickson Publishers, Inc.

26. Greshake, Gisbert. 2000. Il Dio unitrino. Teologia trinitaria, trans. by P. Renner. Brescia: Queriniana.

27. Grillmeier, Aloys. 1975. Christ in Christian Tradition, I: From the Apostolic Age to Chalcedon (451), trans. by J. Bowden. London-Oxford: Mowbray.

28. Hadot, Pierre. 2018. Da Tertulliano a Boezio. Lo sviluppo della nozione di persona nelle controversie teologiche. In Id., Studi di patristica e di storia dei concetti, 389-400. Pisa: Edizioni ETS.

29. Horace. 1942. Satires, Epistles, Ars Poetica, trans. by H. Rushton Fairclough. Cambridge, MA: Harvard University Press.

30. Justin, Philosopher and Martyr. 2009. Apologies, ed. D. Minns and P. Parvis. Oxford: Oxford University Press.

31. Kelly, John N. D. 1968. Early Christian doctrines. London: A. and C. Black.

32. Ladrière, Pierre. 1991. La notion de personne héritière d'une longue tradition. In Biomédecine et devenir de la personne, ed. S. Novaes, 27-85. Paris: Seuil.

33. Lienhard, Joseph T. 2002. "Ousia" and "hypostasis": the Cappadocian settlement and the theology of "One hypostasis". In The Trinity: An interdisciplinary symposium on the Trinity, ed. S. Davis, D. Kendall, and G. O'Collins, 99-121. Oxford: Oxford University Press.

34. Lingua, Graziano. 2006. L'icona, l'idolo e la guerra delle immagini. Milano: Medusa.

35. Maspero, Giulio. 2007. Trinity and man: Gregory of Nyssa's Ad Ablabium. Leiden: Brill.

36. Mauss, Marcel. 1938. Une Catégorie de L'Esprit Humain: La Notion de Personne Celle de "Moi". The Journal of the Royal Anthropological Institute of Great Britain and Ireland 68: 263-281.

37. Meunier, Bernard (ed.). 2006. La personne et le christianisme ancien. Paris: Cerf.

38. Milano, Andrea. 2017. Persona in teologia. Alle origini del significato di persona nel cristianesimo antico. Bologna: EDB.

39. Moingt, Jean. 1966-1969. Théologie trinitaire de Tertullien, 4 Voll. Paris: Aubier.

40. Mondzain, Marie José. 2010. Il commercio degli sguardi, trans. by G. Lingua. Milano: Medusa.

41. Moreschini, Claudio. 2008. I Padri cappadoci. Storia, letteratura, teologia. Roma: Città Nuova.

42. Moreschini, Claudio. 2004. Storia della filosofia patristica. Brescia: Morcelliana.

43. Nédoncelle, Maurice. 1948. Prosōpon et persona dans l'antiquité classique. Essai de bilan linguistique. Revue des Sciences Religieuses 22 (3-4): 277-299.

44. Origen. 1903. In Ioannem, ed. E. Preuschen, in Origenes Werke IV, GSC 10. Leipzig: Hinrichs.

45. Prestige, George. 1952. God in patristic thought. London: S.P.C.K.

46. Rousseau, Philip. 1994. Basil of Caesarea. Los Angeles: University of California.

47. Seeberg, Reinhold. 1895. Lehrbuch der Dogmengeschichte, Erste Hälfte. Erlangen und Lepzig: A. Deichert.

48. Tertullian. 1954. Adversus Praxean, ed. E. Kroymann and E. Evans. CCSL 2. Turnhout: Brepols.

49. Vasiliu, Anca. 2010. Eikōn. L'image dans le discours des trois Cappadociens. Paris: PUF.

50. Vasiliu, Anca. 2017. Eikōn et la pensée trinitaire: prémisses théoriques, in L'icône dans la pensée et dans l'art, ed. K. Mitalaité and A. Vasiliu, 3-21. Turnhout: Brepols.

51. Von Harnack, Adolf. 1902. What is Christianity? Lectures delivered in the University of Berlin during the Winter-term, 1899-1900, trans. by Th.B. Saunders. New York: G.P. Putnam's Sons - London: Williams and Norgate.

Publisher's Note Springer Nature remains neutral with regard to jurisdictional claims in published maps and institutional affiliations. 